\title{
The English Creole Spoken in Panama: A Bibliography
}

\author{
Martín Jamieson \\ Círculo Lingüístico de Panamá
}

The shift from homogeneity to variety in the study of language has contributed to the development of sociolinguistics. This shift has also fomented the ranks of specialists in Creole languages, a confirmed province of this science. The French-based Creoles have been often appraised and A. Valdman's Le créole: structure, statut et origine (Paris: Klincksieck, 1978) is a handy synthesis. Other Creoles (Portuguese-based, Spanish-based, etc.) are still awaiting a summary of equivalent scope. Studies have also been published on the English-based varieties. Of these, the Jamaican dialect extended to Panama has been a poor relation, despite its vigorous presence and special characteristics: it has thrived on the Isthmus of Panama since 1820 where, over the years, fresh waves of West Indian native speakers have contributed to give rise to Isthmian dialects. These offshoots of Jamaican Creole have been in close contact with other Caribbean Creoles (whether English- or French-based); with Spanish, the dominant and official language, and with American English. Scientific interest in Panamanian Creole English has dawned late and there is still much to be done.

The following is a bibliography of (mostly unpublished) pioneering works which establish guidelines for scholars and attest to the growing interest in the language.

Alarcón, Atenaida and Leila C. Fray. Lengua, cultura y bilingüismo en Panamá por parte de los negros afro-antillanos. Unpublished thesis, University of Panama, 1984, XIV, $150 \mathrm{pp}$. Very little on language and bilingualism. Stress is on the Spanish used by the group.

Alfaro, Marcia del C. "El inglés criollo de Panamá y el inglés modelo (standard): algunas consideraciones gramaticales," pp. 34-49, also pp. 141-52 in English. Considers the lack of past marker of Creole verbs as they appear in written Language.

Barrios Montalvo, Josefa. Estudio socio-lingüístico del grupo antillano de la comunidad de Arco Iris. Unpublished thesis, University of Panama (CRU Colón), 1984, XVIII, $227 \mathrm{pp}$. Generational approach applied to the use of Spanish in a West Indian group of Colon province. Only the last of three chapters covers the study of language proper (phonetics and grammar). 
Cohen, Pedro I. "La pronunciación del inglés criollo de Panamá." Primeras jornadas lingüísticas: el inglés criollo de Panamá, pp. 21-31, also pp. 127-40 in English. Contrasts some vowels and consonants of American Standard English and Panamanian Creole English.

Cohen, Pedro, et al. Primeras jornadas lingüisticas: el inglés criollo de Panamá. Panamá: Editorial Universitaria, n. d. [1976], vI, 211 pp. Bilingual publication whose English pages (111-211) reproduce the same articles that are in Spanish in the first half of the volume.

Espinoza C., Edgardo Amaurey. A Brief Syntactic and Morphologic Comparison and Contrast of the English Dialect of Puerto Armuelles with the English Dialect of Colon. Unpublished thesis, University of Panama [David, Chiriquí], 1984, XX, 114 pp. Compares the Puerto Armuelles dialect with the Colon dialect as described by M. M. Spragg.

Fálquez S., Manuel E. A Description of Some Relevant Phonological Features of Chilibre Creole: Vowels and Consonants. Unpublished thesis, University of Panamá, 1983, X, $89 \mathrm{pp}$. Structural analysis of the speech of six informants, ranging from 62 to 81 years of age, four of whom were born in Jamaica, the other two being native to Panama.

Fuentes de Ho, Gloria. "El bilingüismo y sus facetas." Primeras jornadas lingüísticas: el inglés criollo de Panama, pp. 99-107, also pp. 203-11 in English. Phonic interference (four sounds are considered) in the Spanish of bilingual speakers of Creole English of the province of Panama.

García de Bárcenas, Diana, Luzmila Jaén, Edita Tutiven de Mejía. Estudio sociolingüístico del grupo antillano de la comunidad de Nueva Providencia. Unpublished thesis, University of Panama, 1984, XV, 163 pp. In the fifth chapter (pp. 67-134) the Spanish (phonetics, phonology and grammar) of the inhabitants of Nueva Providencia is studied.

Herzfeld, Anita. "Limón Creole and Panamanian Creole: Comparison and Contrast." Les langes crèoles a la lumière de la théorie des langues standard. Ed. Mervin C. Alleyne and Paul L. Garvin. Aruba, 1980, pp. 1-20.

Jamieson Villiers, Martín. "El inglés criollo de Panamá: invitación a su estudio. Apéndice: cinco voces jamaicanas en el español de Panamá." Revue des Langues de l'Institut des Langues Vivantes Etrangères de l'Université d'Oran 1 (1979): 22-39. Elementary introduction in which dialects are mentioned along with Spanish influence on Creole and borrowings from it received by Panamanian Spanish.

Jones, Adelaida Alphonse. "Comparación fonológica del inglés criollo de Panamá y el inglés de los negros de los Estados Unidos de América." Primeras jornadas lingǘsticas: el inglés criollo de Panamá, pp. 85-98, also pp. 189-202 in English. Contrastive analysis of varieties spoken by two black groups whose vernacular are originated in Creole languages and which are subjected to different types of interference.

Justavino, Nilsa Esther. West Indian English Dialects in Panama: A Historical, Social and Linguistic Approach. Unpublished thesis, University of Panama, 1975, XIV, 236 pp. Excellent, comprehensive description of Creole English in the Isthmus, surprisingly 
still unpublished. It covers influences, phonology (including suprasegmentals and juncture), grammar, kinesics and vocabulary.

King de Ward, Rosalía Angélica. An Introduction to the Morphology and Syntax of Rio Abajo English Creole. Unpublished thesis, University of Panama, 1985, XVIr, $207 \mathrm{pp}$. Describes the community and method used for the study of patterns of 20 informants from Río Abajo, in the province of Panama. Structural approach.

Mason, Norma. Common Problems in the Use of Prepositions by Native Speakers of Spanish and Speakers of Creole English. Unpublished thesis, University of Panama, 1979, $121 \mathrm{pp}$. Speakers of Creole English omit or use superfluous prepositions, misuse and mispronounce them and, when writing, misspell them. Teaching recommendations are included.

Pierre, Esteban. Difficulties Most Colon Creole English Speakers might Encounter when Learning Standard English. Unpublished thesis, University of Panama, 1987, 90 pp. Contrastive study (phonics, grammar and vocabulary) of Standard American English and Colon Creole English, with pedagogical recommendations.

Rodríguez, Emigdio O. "Pasado, presente y futuro del inglés criollo de Panamá." Primeras jornadas lingüisticas: el inglés criollo de Panamá, pp. 2-19, also pp. 111-26 in English. Comments on the need to study Creole English in Panama.

Robinson A., Dolores Estela. Problems that West Indian Students Encounter when They Are Learning to Write Standard English. Unpublished thesis, University of Panama, 1982, $76 \mathrm{pp}$. Morphosyntactic analysis of transfers from Spanish and Creole in the written Standard English of Creole speakers from the province of Colon.

Spragg, Marva Myles. "Naturaleza del dialecto inglés de Colón." Primeras jornadas lingüisticas: el inglés criollo de Panamá, pp. 51-83, also pp. 153-88 in English. Description of the phonology of Colon English Creole compared to American Standard English. Comments on morphology and syntax. (This is a partial publication of her Origin and Nature mentioned below.)

Spragg, Marva Myles. Origin and Nature of the English of Colon and its Implications for the Teaching of Standard English. Unpublished thesis, University of Panama, 1973, IV, $99 \mathrm{pp}$. Study of grammar and pronunciation, including stress and pitch, of the English of the Atlantic city of Colon. 